
This work was supported by the US Department of Energy, Division of Geothermal Energy.

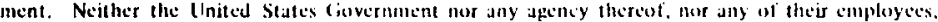

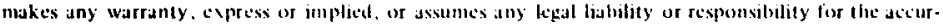
wey, completencss, or usefulmess of any informations. apparalus, product, or process disclosed, or represents that its use would not infringe privately owned rights. Reference hercin to any specific consmercial product. process, or service by trade name, trademark. manufacturer or otherwise, does not necessarily constifute or imply its endorsement, recommendation, or favoring by the tinted Stutes Government or any agency thereot. The views and opinions of authors copressed herein dos not necessurily stati or retlect thuse of the United States ciovernment or any apency thereot. 


\title{
Geology and Geochemistry of Samples from Los Alamos National Laboratory HDR Well EE-2, Fenton Hill, New Mexico
}

\author{
R. Laney \\ A. W. Laughlin \\ M. J. Aldrich, Jr.
}
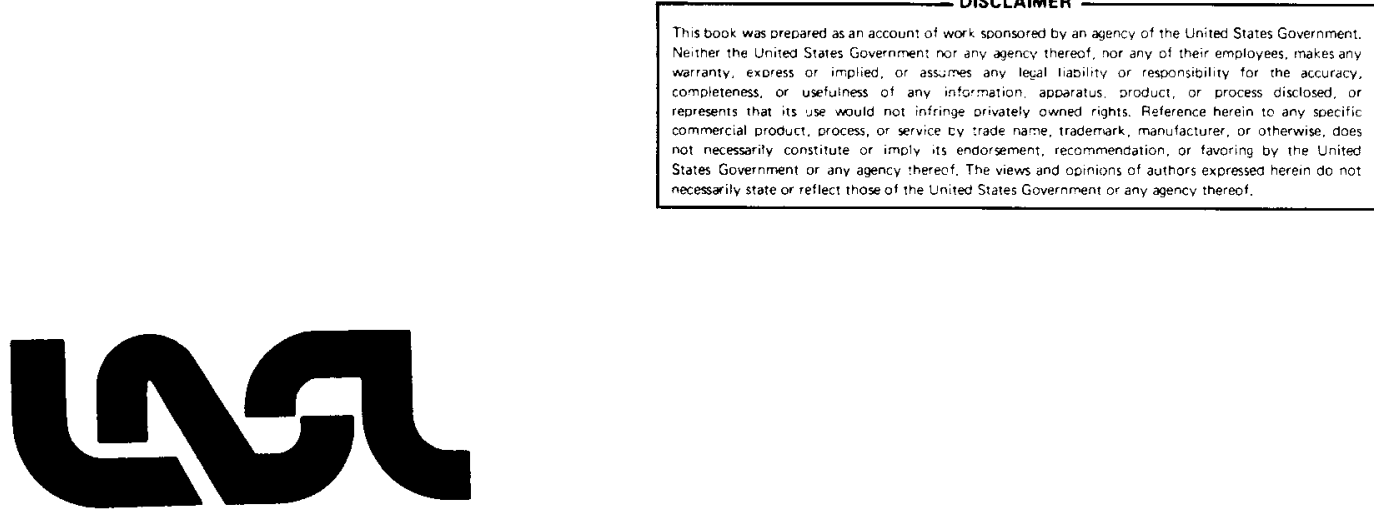


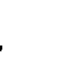

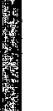

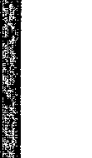

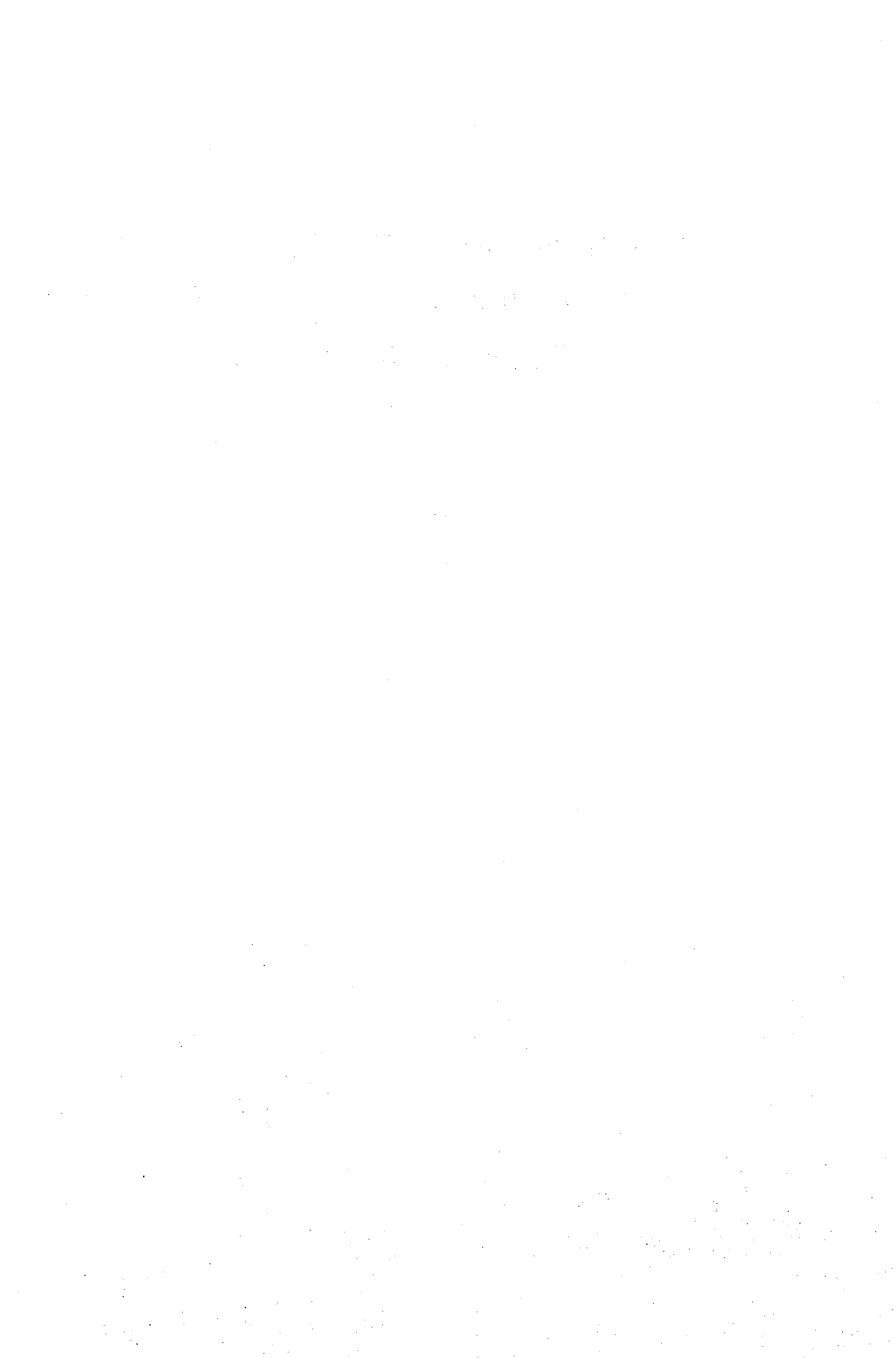


GEOLOGY AND GEOCHEMISTRY OF SAMPLES FROM LOS ALAMOS

NATIONAL LABORATORY HDR WELL EE-2, FENTON HILL, NEW MEXICO

by

R. Laney, A. W. Laughlin, and M. J. Aldrich, Jr.

\begin{abstract}
Petrologic, geochemical, and structural analyses of cores and cuttings obtained from 3000 to $4389-m$ true vertical depth in drill hole EE-2 indicate that this deeper part of the Precambrian section at Fenton Hill, New Mexico is composed primarily of a very heterogeneous and structurally anisotropic metamorphic complex, locally intruded by dikes and sills of granodioritic and monzogranitic composition. In this borehole none of these igneous bodies approach in size the 335-m-thick biotitegranodiorite body encountered at 2591-m depth beneath Fenton Hill in the other two drill holes. Contacts between the igneous and metamorphic rocks range from sharp and di scordant to gradational.

Analysis of cuttings indicates that clay-rich alteration zones are relatively common in the openhole portion of $\mathrm{EE}-2$. These zones average about $20 \mathrm{~m}$ in thickness.

Fracture sets in the Precambrian basement rock intersected by the EE-2 well bore mostly trend northeast and are steeply dipping to vertical; however, one of the sets dips gently to the northwest. Slickensided fault planes are present in a core (\#5) taken from a true vertical depth of $4195 \mathrm{~m}$. Available core orientation data and geologic inference suggest that the faults dip steeply and trend between $\mathrm{N} .42^{\circ}$ and $59^{\circ} \mathrm{E}$.

It is apparent from these results that the interval in which the Phase II Hot Dry Rock system will be developed is very different from that where the Phase I system was developed. The potential Phase II reservoir is much more heterogeneous. It contains no single, large, homogeneous lithologic unit. Clay-rich alteration zones may open during hydraulic fracturing and permit water loss during energy extraction. They al so could serve as sources of fine-grained clay that might plug hydraulic fractures or contaminate water pumped through the circulation 100p.
\end{abstract}




\section{INTRODUCTION}

For approximately $7 \mathrm{yr}$, the Los Alamos National Laboratory has been investigating a method of extracting geothermal energy from rocks of low natural permeability. These experiments are being conducted at Fenton $\mathrm{Hill}$ on the western flank of the Valles Caldera in the Jemez Mountains of northern New Mexico. To date, three deep drill holes (GT-2, EE-1, and EE-2) have been completed, and the drilling of a fourth (EE-3) is in progress. Drill hole GT-2 reached a depth of approximately $2929 \mathrm{~m}$ and a bottomhole temperature of $197^{\circ} \mathrm{C}$, EE-1 a depth of approximately $3062 \mathrm{~m}$ and a bottomhole temperature of $205.5^{\circ} \mathrm{C}$, and $E E-2$ has a true vertical depth of $4389.3 \mathrm{~m}$ and a bottomhole temperature of $323^{\circ} \mathrm{C}$. Drill hole EE-2 penetrated approximately $3600 \mathrm{~m}$ of Precambrian rocks, providing samples of the potential reservoir rocks where the Phase II Hot Dry Rock (HDR) system will be developed.

The geologic setting of the Fenton Hill drill site and its relation to the other geothermal systems of the Jemez Mountains have been discussed by West (1973), Laughl in and Eddy (1977), and Laughlin (1981). Laughl in and Eddy (1977) also described in detail the petrology and geochemistry of the Precambrian rocks to a depth of $3062 \mathrm{~m}$ (the bottom of EE-1).

Approximately $75 \%$ of the Precambrian section sampled by GT-2 and EE-1 is an extremely variable gneissic complex that is strongly foliated. It ranges from syenogranitic to tonalitic in composition with the bulk falling within the monzogranitic field. An amphibole-biotite schist is interlayered with the gneisses. The remainder of the section is made up of at least two 15-m-thick monzogranite dikes, intrusive into the metamorphic complex, and a biotitegranodiorite body intercepted by the lowermost $338 \mathrm{~m}$ of drill hole GT-2 and the corresponding interval in EE-1.

\section{ANALYSIS OF CORES AND CUTTINGS FROM EE-2}

A. Discussion of Analytical Methods

Samples of the basement rocks were provided by six short cores, by cuttings collected at approximately three meter intervals, and by "junk basket" samples. The latter were chips and slabs of rock that spalled from the walls of the drill hole and were recovered by a junk basket behind the drill bit during interruptions in the drilling. Because the Precambrian section above a depth of $3 \mathrm{~km}$ had been previously well characterized by samples from drill 
holes GT-2 and EE-1 (Laughlin and Eddy 1976, 1977; Brookins et al. 1977), the six EE-2 cores, totaling $857 \mathrm{~cm}$, were taken from the interval $3000 \mathrm{~m}$ to 4389 $m$. Examination of cuttings and junk basket samples al so concentrated on this interval.

Rock cuttings and cores retrieved during the drilling of exploratory and development wells in an HDR prospect area represent the most important data for the analysis and evaluation of the geology. Although cores yield the most reliable data concerning rock stratigraphy and reservoir properties, economic constraints usually severely limit the amount of material that can be cored. In the case of EE-2, the six cores that were retrieved represent only one-half of one percent of the entire vertical dimension of the reservoir rock. In contrast, cuttings represent a nearly continuous record of the rock penetrated. Because cores can be used to "calibrate" the cuttings analysis, the two types of material are complementary.

Six cores were recovered during the drilling of EE-2; one coring attempt produced no core, apparently because of extensive rock alteration. Depths along the well bore, true vertical depths, and brief descriptions of these cores are given in Table I. More detailed descriptions of the petrological and geochemical aspects of the cores are presented in the next section.

Thin sections have been prepared of the representative lithologies sampled by the EE-2 drill hole. Standard petrographic techniques were used for mineral identification and a manual point counter employed for modal analysis. Results of the modal analyses are presented in Table II. Rock names were assigned on the basis of the relative proportions of quartz (Q), alkali feldspar (A), and plagioclase (P). Figure 1 illustrates the classification used in this report. Chemical analyses that have been completed on 11 samples from the $6 \mathrm{EE}-2$ cores are shown in Table III.

Al though rock cuttings are extremely valuable geologic material, cuttings analysis is fraught with many problems. Certain biases occur during recovery, sampling, and analysis. For example, rock cuttings become mixed (to an unknown degree) on the way to the surface. For lithologic units of limited vertical thickness $(0.3$ to $1.5 \mathrm{~m})$, this mixing can cause these units to effectively "disappear" or blend into the surrounding rock cuttings so that the thin units are not recognized. This happened in GT-2 and EE-1 where thin amphibolite and biotite schist units were not identified in the cuttings but were quite apparent on the spectral gamma logs (West and Laughl in 1976). 
TABLE I

CORING HISTORY OF EE-2

\begin{tabular}{|c|c|c|c|c|}
\hline Core No. & $\begin{array}{c}\text { Coring } \\
\text { Interval (m) }\end{array}$ & $\begin{array}{c}\text { True Vertical } \\
\text { Depth (m) } \\
\end{array}$ & Temp. ${ }^{\circ} \mathrm{C}$ & Megascopic Aspect \\
\hline 1 & $3577.6-3579.5$ & $3501.8-3503.3$ & 239 & $\begin{array}{l}\text { Biotite-granodiorite } \\
\text { gneiss intruded by fine- } \\
\text { grained monzogranite. }\end{array}$ \\
\hline 2 & $3916.1-3918.5$ & $3779.3-3781.3$ & 263 & $\begin{array}{l}\text { Mafic metavolcanic in- } \\
\text { truded by granitic rock. }\end{array}$ \\
\hline 3 & $4100.8-4103.8$ & $3930.8-3933.3$ & 277 & Biotite granodiorite. \\
\hline 4 & $4253.5-4255.8$ & $4057.8-4059.7$ & 288 & $\begin{array}{l}\text { Biotite-rich augen gneiss } \\
\text { intruded by fine-grained } \\
\text { biotite monzogranite. }\end{array}$ \\
\hline 5 & $4419.9-4420.8$ & $4194.3-4195.1$ & 302 & $\begin{array}{l}\text { Biotite-rich gneiss. } \\
\text { slickensided fault plane } \\
\text { parallels axis of core. }\end{array}$ \\
\hline 6 & $4560.4-4561.6$ & $4309.5-4310.5$ & 313 & $\begin{array}{l}\text { Bi otite-granodiorite } \\
\text { gneiss intruded by fine- } \\
\text { grained granodiorite. }\end{array}$ \\
\hline
\end{tabular}


TABLE II

RESULTS OF MODAL ANALYSIS OF EE-2 SAMPLES

\begin{tabular}{|c|c|c|c|c|c|c|c|c|c|}
\hline $\begin{array}{l}\text { Core No. } \\
\text { Sample No. }\end{array}$ & $\frac{1}{11738-1 A}$ & $\frac{1}{11741-1 A}$ & $\frac{1}{11743-3 A}$ & $\begin{array}{c}1 \\
11743-3 B\end{array}$ & $\frac{1}{11743-3 C}$ & $\stackrel{2}{2}$ & $\stackrel{2}{12854-6}$ & $\stackrel{2}{2}$ & $\stackrel{2}{12849-3 A F}$ \\
\hline K-feldspar & 38.7 & 6.4 & 10.9 & 17.2 & 10.6 & 2.0 & 5.0 & 2.1 & 23.7 \\
\hline Plagioclase & 23.0 & 38.6 & 33.1 & 23.3 & 25.6 & 22.9 & 24.0 & 14.8 & 27.4 \\
\hline$\% A n^{a}$ & 16 & 30 & - & - & - & 26 & - & - & - \\
\hline Quartz & 32.9 & 37.0 & 27.5 & 34.5 & 33.8 & 11.6 & 7.9 & 8.2 & 32.0 \\
\hline Biotite & 0.7 & 12.3 & 18.8 & 18.5 & 19.8 & 34.9 & 35.4 & 42.5 & 5.9 \\
\hline Chlorite & 1.2 & 0.5 & 0.9 & 0.6 & - & - & - & - & $<0.1$ \\
\hline Opaques & 0.2 & 0.7 & 1.5 & 0.8 & 2.0 & 5.4 & 6.9 & 9.7 & 1.7 \\
\hline Muscovite & 0.6 & $<0.1$ & 0.5 & 0.6 & 0.6 & - & - & - & $\operatorname{Tr}$ \\
\hline Myrmeki te & 0.3 & 0.4 & 0.5 & 0.2 & 0.6 & - & - & - & 0.9 \\
\hline Calcite & 0.5 & 0.4 & 0.7 & 0.4 & $<0.1$ & - & - & - & 1.6 \\
\hline Epidote & 1.3 & 2.6 & 3.5 & 2.1 & 3.9 & 2.3 & 5.6 & 5.1 & 2.7 \\
\hline Apatite & 0.2 & 0.2 & 0.2 & 0.3 & $<0.1$ & 4.3 & 3.7 & 5.7 & 1.2 \\
\hline Sphene & - & 0.7 & 1.8 & 1.4 & 2.5 & 8.1 & 8.2 & 9.9 & 1.2 \\
\hline Zircon & - & 0.1 & 0.1 & 0.1 & 0.1 & - & - & - & 0.3 \\
\hline Amphibole & - & - & - & - & - & 8.2 & 3.2 & 1.7 & 0.9 \\
\hline Rutile & 0.3 & $<0.1$ & - & - & - & - & - & - & - \\
\hline Prehnite & $<0.1$ & - & - & 0.1 & 0.3 & - & - & - & - \\
\hline Allanite & - & - & - & - & - & $<0.1$ & $<0.2$ & $<0.2$ & $<0.3$ \\
\hline Remarks: & $\begin{array}{l}\text { Fel sic } \\
\text { Intrusive }\end{array}$ & $\begin{array}{l}\text { Middle } \\
\text { of Core }\end{array}$ & $\stackrel{\perp \text { to }}{\text { Foliation }}$ & $\begin{array}{l}\perp \text { to } \\
\text { Foliation }\end{array}$ & $\begin{array}{l}\text { Parallel } \\
\text { to Folia- } \\
\text { tion }\end{array}$ & Mafic & Mafic & Mafic & Felsic \\
\hline Rock Type & M.G. & B.G.G. & B.G.G. & B.G.G. & B.G.G. & M.V. & M.V. & M.V. & B.M.G. \\
\hline $\begin{array}{l}\text { Key: Bioti } \\
\text { Monzo } \\
\text { Bioti } \\
\text { Bioti } \\
\text { Tonal } \\
\text { Metav } \\
\end{array}$ & $\begin{array}{l}\text { Granodior } \\
\text { anite - M. } \\
\text { Monzogran } \\
\text { Granodior } \\
\text { ic Gneiss } \\
\text { canic Rock }\end{array}$ & $\begin{array}{l}\text { te - B.G. } \\
\text { te - B.M.G. } \\
\text { tic Gneiss } \\
\text { T.G. } \\
\text { - M.V. }\end{array}$ & B.G.G. & & & & & & \\
\hline
\end{tabular}

Determined by electron microprobe. 


\begin{tabular}{|c|c|c|c|c|c|c|c|c|c|}
\hline $\begin{array}{l}\text { Core No. } \\
\text { Sample No. }\end{array}$ & $\stackrel{2}{12853-2}$ & $\stackrel{3}{13461-2 B}$ & $\stackrel{3}{13461-2 A}$ & $\stackrel{3}{3}$ & $\begin{array}{c}3 \\
13463-18\end{array}$ & $\stackrel{4}{13956-2 A}$ & $\begin{array}{c}4 \\
13956-2 B\end{array}$ & $\begin{array}{c}4 \\
13956-4 A\end{array}$ & $\begin{array}{c}4 \\
13956-4 B\end{array}$ \\
\hline K-feldspar & 27.0 & 17.3 & 9.7 & 26.1 & 19.7 & 0.4 & - & - & - \\
\hline Plagioclase & 22.2 & 37.1 & 39.7 & 30.3 & 26.5 & 43.2 & 28.0 & 39.1 & 44.7 \\
\hline$\%$ An & - & 25 & - & - & - & - & 36 & - & - \\
\hline Quartz & 23.8 & 21.2 & 24.9 & 21.1 & 26.3 & 30.3 & 17.6 & 25.9 & 17.9 \\
\hline Biotite & 14.3 & 12.7 & 9.0 & 8.9 & 16.3 & 13.0 & 19.7 & 12.1 & 13.1 \\
\hline Chlorite & $<0.3$ & 0.5 & 2.1 & 0.9 & 0.3 & 0.9 & 1.2 & 0.6 & 0.6 \\
\hline Opaques & 3.1 & 1.9 & 3.0 & 3.5 & 2.4 & $<0.1$ & 0.1 & 0.4 & 0.6 \\
\hline Muscovite & $<0.3$ & 0.9 & 1.2 & 0.8 & $<0.5$ & $<0.1$ & 0.1 & 0.1 & $<0.1$ \\
\hline Myrmeki te & - & 0.4 & $<0.2$ & $<0.2$ & 0.8 & - & - & - & - \\
\hline Calcite & 0.5 & 0.7 & 0.9 & 0.6 & $<0.5$ & 0.6 & 0.3 & 0.3 & 0.3 \\
\hline Epidote & 1.7 & 4.2 & 4.4 & 3.7 & 2.9 & 2.6 & 4.1 & 2.4 & 2.9 \\
\hline Apatite & 2.2 & 0.1 & $<0.1$ & $<0.2$ & - & 0.1 & 0.1 & $<0.1$ & - \\
\hline Sphene & 3.3 & 2.1 & 2.0 & 2.8 & 3.1 & 1.1 & 3.1 & 0.9 & 2.5 \\
\hline Zircon & $<0.1$ & 0.1 & $<0.2$ & $<0.1$ & 0.1 & - & - & - & - \\
\hline Amphibole & 1.4 & - & - & - & 0.3 & 7.9 & 25.4 & 17.7 & 18.2 \\
\hline Rutile & - & - & - & - & - & - & - & - & - \\
\hline Prehnite & - & 0.7 & 2.3 & 0.9 & $<0.1$ & - & - & - & - \\
\hline Allanite & $<0.1$ & $<0.1$ & $<0.2$ & - & 0.1 & - & $<0.1$ & - & - \\
\hline Remarks: & Altered & Equigran. & Equigran. & Equigran. & Equi gran. & Gneissic & Gneissic & Gneissic & Gneissic \\
\hline Rock Type: & M.V. & B.G. & B.G. & B.G. & B.G. & T.G. & T.G. & T.G. & T.G. \\
\hline
\end{tabular}


TABLE II (cont)

\begin{tabular}{|c|c|c|c|c|c|}
\hline $\begin{array}{l}\text { Core No. } \\
\text { Sample No. }\end{array}$ & $\begin{array}{c}4 \\
13955-5\end{array}$ & $\begin{array}{c}4 \\
13961-28\end{array}$ & $\begin{array}{c}5 \\
14502-2 C\end{array}$ & $\begin{array}{c}6 \\
14965-2 C 1\end{array}$ & $\begin{array}{c}6 \\
14965-2 C 2\end{array}$ \\
\hline K-feldspar & - & 37.4 & 2.4 & 5.3 & 3.8 \\
\hline Plagioclase & 38.0 & 21.8 & 29.0 & 35.5 & 37.7 \\
\hline \& An & - & - & $41-31$ & - & 30 \\
\hline Quartz & 22.8 & 30.6 & 17.4 & 34.2 & 34.0 \\
\hline Biotite & 11.6 & 6.3 & 12.6 & 11.9 & 15.4 \\
\hline Chlorite & 0.8 & 0.6 & - & 5.6 & 3.8 \\
\hline Opaques & $<0.3$ & $<1$ & $<0.1$ & 1.8 & 0.9 \\
\hline Muscovite & 0.1 & 2.1 & 3.7 & 2.0 & 1.9 \\
\hline Mynmekite & - & - & 0 & 0.9 & $\operatorname{Tr}$ \\
\hline Calcite & 0.2 & 0.6 & 0.5 & $T r$ & $T r$ \\
\hline Epidote & 3.4 & 0.4 & 0.5 & 1.8 & 0.9 \\
\hline Apatite & 0.1 & - & - & - & - \\
\hline Sphene & 1.8 & $\operatorname{Tr}$ & 0.5 & 0.9 & 1.6 \\
\hline Zircon & - & $\operatorname{Tr}$ & $<0.3$ & - & - \\
\hline Amphibole & 20.8 & - & 33.1 & - & - \\
\hline Rutile & - & - & - & - & - \\
\hline Prehnite & - & - & - & - & - \\
\hline Allanite & - & $\operatorname{Tr}$ & - & $\operatorname{Tr}$ & $\operatorname{Tr}$ \\
\hline Remarks: & Gneissic & Equigran. & Gneissic & Gnetssic & Gneissic \\
\hline Rock Type: & T.G. & B.M.G. & T.G. & B.G.G. & B.G.G. \\
\hline
\end{tabular}


TABLE III

CHEMICAL ANALYSES OF PRECAMBRIAN ROCKS FROM DRILL HOLE EE-2

\begin{tabular}{|c|c|c|c|c|c|c|}
\hline Core No. & 1 & 1 & 2 & 2 & 2 & 2 \\
\hline Sample No. & $11738-1$ & $11740-1$ & $12848-4$ & $12848-6$ & $12849-3 a$ & $12849-3 b$ \\
\hline $\mathrm{SiO}_{2}$ & 71.99 & 66.50 & 66.16 & 59.96 & 59.49 & 69.83 \\
\hline $\mathrm{Al}_{2} \mathrm{O}_{3}$ & 14.75 & 15.20 & 14.95 & 14.80 & 14.50 & 14.32 \\
\hline $\mathrm{Fe}_{2} \mathrm{O}_{3}$ & 0.64 & 1.90 & 2.22 & 2.90 & 3.40 & 1.46 \\
\hline $\mathrm{FeO}$ & 1.07 & 2.43 & 2.73 & 4.50 & 4.84 & 1.65 \\
\hline $\mathrm{MgO}$ & 0.49 & 1.44 & 1.29 & 2.48 & 2.57 & 0.73 \\
\hline $\mathrm{CaO}$ & 1.66 & 3.26 & 2.86 & 4.44 & 4.36 & 2.30 \\
\hline $\mathrm{Na}_{2} \mathrm{O}$ & 3.59 & 3.74 & 3.20 & 3.15 & 3.52 & 2.93 \\
\hline $\mathrm{K}_{2} \mathrm{O}$ & 4.32 & 2.71 & 4.20 & 3.31 & 3.04 & 5.10 \\
\hline $\mathrm{H}_{2} \mathrm{O}^{+}$ & 0.72 & 1.33 & 0.76 & 1.08 & 1.13 & 0.59 \\
\hline $\mathrm{H}_{2} \mathrm{O}^{-}$ & 0.08 & 0.02 & 0.00 & 0.08 & $<0.01$ & $<0.01$ \\
\hline $\mathrm{T} \mathrm{O}_{2}$ & 0.18 & 0.74 & 0.82 & 1.80 & 1.85 & 0.51 \\
\hline $\mathrm{P}_{2} \mathrm{O}_{5}$ & 0.05 & 0.20 & 0.31 & 0.82 & 0.81 & 0.20 \\
\hline MnO & 0.052 & 0.087 & 0.074 & 0.135 & 0.127 & 0.045 \\
\hline Sro & 0.018 & 0.035 & 0.039 & 0.040 & 0.040 & 0.042 \\
\hline Sulfur & $<0.1$ & $<0.1$ & $<0.1$ & $<0.1$ & $<0.1$ & $<0.1$ \\
\hline Total & 99.61 & 99.59 & 99.61 & 99.58 & 99.79 & 99.72 \\
\hline Rock Type & M.G. & B.G.G. & $\begin{array}{c}\text { Mixed } \\
\text { M.V.-B.M,G. }\end{array}$ & M.V. & M.V. & B.M.G. \\
\hline
\end{tabular}

a Analyses done by John Husler, University of New Mexico. 
TABLE III (cont)

\begin{tabular}{|c|c|c|c|c|c|}
\hline \multirow{2}{*}{$\begin{array}{l}\text { Core No. } \\
\text { Sample No. }\end{array}$} & 3 & 4 & 4 & 5 & 6 \\
\hline & $13463-22$ & $13955-3$ & $13962-2$ & $14504-3$ & $14965-4$ \\
\hline $\mathrm{SiO}_{2}$ & 65.02 & 59.43 & 67.68 & 67.06 & 66.59 \\
\hline $\mathrm{Al}_{2} \mathrm{O}_{3}$ & 15.00 & 16.12 & 16.60 & 13.90 & 14.50 \\
\hline $\mathrm{Fe}_{2} \mathrm{O}_{3}$ & 2.73 & 2.08 & 1.01 & 0.99 & 2.25 \\
\hline $\mathrm{Fe} 0$ & 2.67 & 5.15 & 2.06 & 3.61 & 3.01 \\
\hline $\mathrm{Mg} 0$ & 1.39 & 3.40 & 0.98 & 2.16 & 1.57 \\
\hline $\mathrm{CaO}$ & 3.26 & 6.11 & 2.82 & 4.22 & 3.66 \\
\hline $\mathrm{Na}_{2} \mathrm{O}$ & 3.15 & 3.34 & 3.52 & 3.13 & 3.60 \\
\hline $\mathrm{K}_{2} \mathrm{O}$ & 4.1 .9 & 1.53 & 3.48 & 1.30 & 2.20 \\
\hline $\mathrm{H}_{2} \mathrm{O}^{+}$ & 0.92 & 1.19 & 0.83 & 1.45 & 0.92 \\
\hline $\mathrm{H}_{2} \mathrm{O}^{-}$ & 0.06 & 0.24 & 0.00 & 0.06 & 0.02 \\
\hline $\mathrm{T} \mathrm{O}_{2}$ & 0.93 & 0.98 & 0.37 & 0.59 & 0.82 \\
\hline $\mathrm{P}_{2} \mathrm{O}_{5}$ & 0.42 & 0.19 & 0.10 & 0.02 & 0.23 \\
\hline Mno & 0.099 & 0.134 & 0.051 & 0.121 & 0.092 \\
\hline sro & 0.041 & 0.036 & 0.037 & 0.025 & 0.036 \\
\hline Sulfur & $<0.1$ & $<0.1$ & $<0.1$ & $<0.1$ & $<0.1$ \\
\hline Tota1 & 99.88 & 99.93 & 99.54 & 99.64 & 99.50 \\
\hline Rock Type & B.G. & T. G. & B.M.G. & T.G. & B.G.G. \\
\hline
\end{tabular}



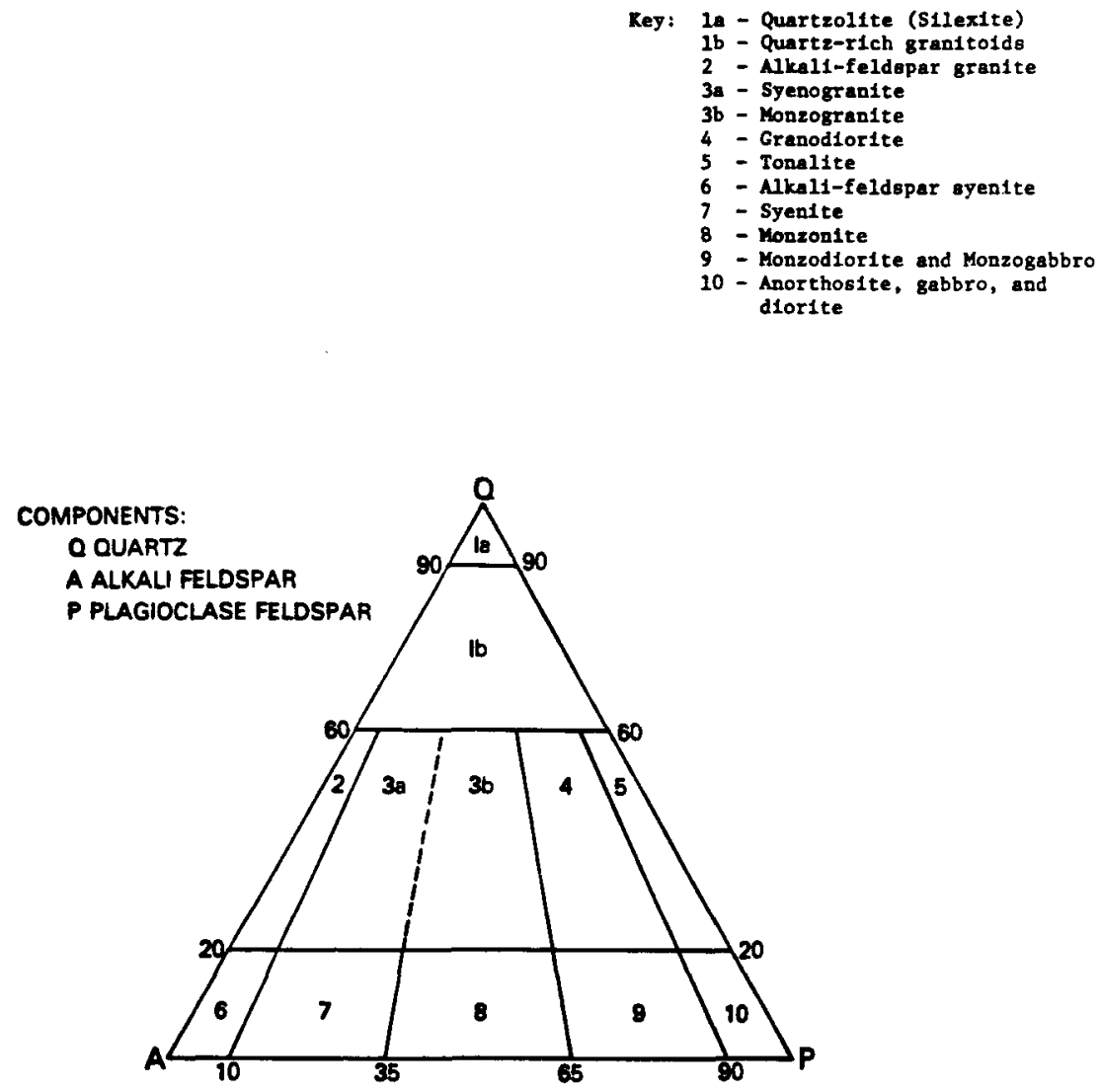

Fig. 1 .

Q-A-P diagram for igneous rocks [International Union of Geological Sciences (IUGS) classification].

Probably in EE-2, cuttings from relatively thin units also have been lost in rock cuttings from surrounding, more massive units. The mixing process becomes more significant, and thus more detrimental to the geologic evaluation, with increasing borehole depth. For wells with a depth on the order of $4600 \mathrm{~m}(15000 \mathrm{ft})$, units of 3 - to $5-\mathrm{m}$ thickness often may escape recognition.

Another problem is the bias that occurs when trying to assign a rock name to a cuttings sample. It is our experience (Laughlin and Eddy 1977, and present work) that feldspars tend to be more finely ground, under the action of tungsten carbide button inserts, than quartz and biotite. Ground rock less than 320 mesh tends to be washed away and 10st. Also, the human eye is more aware of the larger fragments in the sample and less aware of the very minute grains, even though these smaller fragments may be volumetrically more significant. Thus in both sampling and analyzing the cuttings, the volume percent of feldspars may be underestimated and biotite and quartz overestimated. 
We have tried to avoid such biases during this study by limiting our cuttings analysis to a certain size fraction of the cuttings material. To aid in the identification, solid core material was ground to simulate recovered cuttings. We then used these "simulated cuttings" as standards of comparison.

Rock cuttings from EE-2 were collected at approximately 3.1-m (10-ft) intervals over the entire well bore. A visual and binocular check of $30-\mathrm{g}$ splits from each sample was made for color and gross mineralogy. This information was used to define lithologic breaks. Representative samples were then taken from each lithologic unit, sieved, and the -60 to +230 fraction examined closely and/or point counted (approximately 200-300 points). If required, the fraction was compared to previously hand-ground core material. Usually it was then possible to assign a rock type to the cuttings sample.

B. Petrology and Geochemistry of Core Samples

1. Core Number 1. This 1.9-m core is composed of two lithologic units, a coarse-grained biotite-granodiorite gneiss and an intrusive, finer-grained monzogranite. Contacts between the two rocks are sharply discordant.

Within the gneiss, the $K$-feldspar (microcline) is unaltered and commonly shows tartan twinning. In contrast, most plagioclase $\left(\mathrm{An}_{30}\right)$ is altered to muscovite or sericite. Abundant biotite (17\%, average of four samples), is generally unaltered; less than $1 \%$ chlorite is typically present in the thin sections. Contacts between discrete quartz grains and between quartz and feldspar grains are usually sutured. Opaques, comprising up to $2 \%$ of the rock, consist of two phases that have not been identified. Epidote contents range from about 2 to $4 \%$; the grains are anhedral to subhedral. Anhedral to subhedral sphene grains comprise 0.7 to $2.5 \%$ of the rock. Trace amounts of myrmekite, calcite, apatite, zircon, rutile, and prehnite are al so present.

Chemically, the biotite-granodiorite gneiss of core number 1 is almost identical to the typical biotite-granodiorite gneiss of GT-2 and EE-1 (Laughtin and Eddy 1977).

The monzogranite, intrusive into the biotite-granodiorite gneiss, consists almost entirely of $K$-feldspar, $p l a g i o c l a s e$, and quartz in roughly equivalent amounts. As in the gneiss, the $K-f e l d s p a r$ is unaltered whereas the plagioclase $\left(A n_{16}\right)$ is frequently altered to muscovite or sericite. Quartz grains show sutured contacts. Only two other minerals are present in amounts exceeding $1 \%$, chlorite $(1.2 \%)$ and epidote $(1.3 \%)$. The chlorite is present both as discrete grains and as alteration of biotite grains. In contrast to 
the gneiss, no sphene is present in the monzogranite. There are trace amounts of biotite, opaques, muscovite, myrmekite, calcite, apatite, rutile, and prehnite. The modal composition of this rock is very similar to the composition of the monzogranite dike intersected by drill hole GT-2 at a depth of 1304 to $1306 \mathrm{~m}$ (Laughlin and Eddy 1977). The whole rock chemical composition is also almost identical to that of the GT-2 sample (Table IV). Both rocks have high silica and alkali contents and low $\mathrm{TiO}_{2}$ and $\mathrm{P}_{2} \mathrm{O}_{5}$ contents when compared with the intrusive granodiorites. Both the GT-2 and EE-2 monzogranite samples probably crystallized from the same magma.

2. Core Number 2. The second core $(2.4 \mathrm{~m}$ long) is composed of a metamorphosed-mafic volcanic (or fine-grained intrusive) rock and a biotite monzogranite. The monzogranite discordantly intrudes the metavolcanic rock and contains xenoliths of it. Contacts between the xenoliths and the monzogranite commonly are complex. Small stringers or dikes of the monzogranite are present within the metavolcanic rock, and in general the core shows considerable evidence of both forceful injection and magmatic reaction between the monzogranitic magma and the metavolcanic rock.

The metavolcanic rock is fine grained, generally equigranular, and nonfoliated. Scattered, rare porphyroblasts or relict phenocrysts of plagioclase are present. Mineralogically, the rock contains abundant biotite (35-43\%), plagioclase (15-24\%), quartz (8-12\%), and opaques (5-10\%). Less abundant are amphibole (2-8\%) and K-feldspar (2-5\%). Epidote and sphene, which are usually thought of as trace constituents, are abundant in this rock with epidote ranging from 2 to $6 \%$ and sphene from 8 to 10\%. Needle-like grains of apatite make up from 4 to $6 \%$ of the rock. Trace amounts of allanite are also present.

In contrast to the plagioclase in other Fenton Hill Precambrian samples, the plagioclase in the metavolcanic rock is remarkably unaltered. No sericitic alteration was observed. Sphene in this rock is also very different in that it shows strong evidence of resorption.

Both mineralogically and chemically the metavolcanic rock is very different from other rocks encountered in GT-2, EE-1, or EE-2. Compared to the mafic schists and amphibolites of GT-2, for example, the metavolcanic rock contains much less plagioclase and much more sphene. As a result, the $\mathrm{Al}_{2} \mathrm{O}_{3}$ content of the metavolcanic is lower and the $\mathrm{TiO}_{2}$ content slightly higher. The $\mathrm{P}_{2} \mathrm{O}_{5}$ content is al so higher in the metavol canic rock of EE-2. 
TABLE IV

PRECAMBRIAN INTRUSIVE IGNEOUS ROCKS FROM DEEP HOLES EE-2 AND GT-2

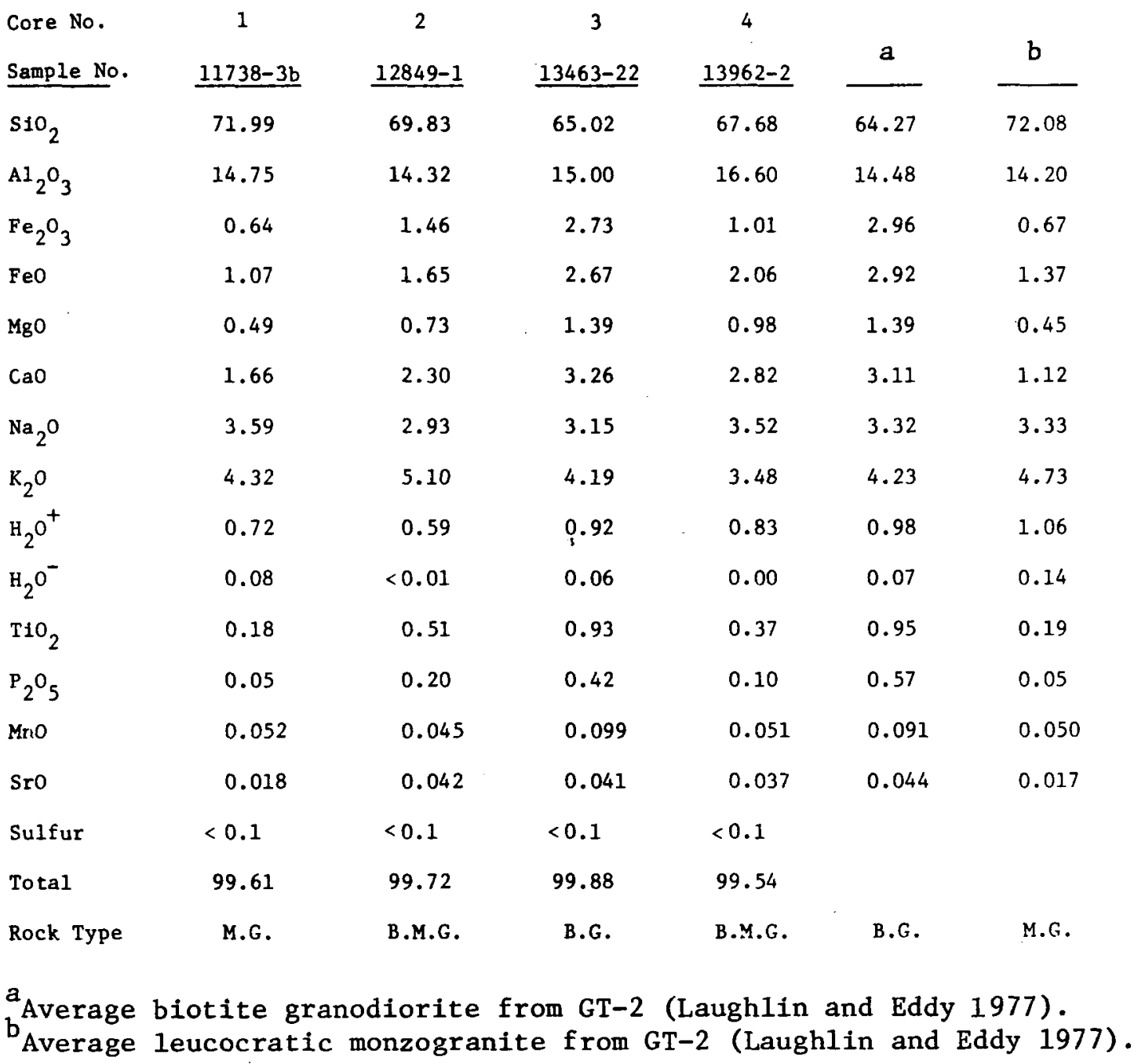


The biotite monzogranite from core number 2 is composed primarily of quartz, K-feldspar, and plagioclase. Biotite makes up about $6 \%$ of the rock, amphibole about $1 \%$, and epidote about $2.7 \%$. About $1.7 \%$ opaques, $1.6 \%$ calcite, and $1.2 \%$ sphene are present. Present in trace amounts are chlorite, myrmekite, apatite, zircon, allanite, and the small needle-like crystals of apatite observed in the metavolcanic rock. In contrast to the plagioclase, which may occasionally be altered to sericite, the $K$-feldspar (microcline) is invariably unaltered. Quartz grain contacts are typically sutured. Opaque mineral grains are composed of at least two phases and are commonly clustered into clots. In general, sphene grains are subhedral to euhedral in form.

The biotite monzogranite from core number 2 may be distinguished from the monzogranite from core number 1 by the greater abundance of biotite and opaques, the lower abundance of $K$-feldspar, and the presence of sphene and amphibole.

3. Core Number 3. Al though there is a considerable variation in mineral abundances over short distances within this core, the variations are uniformly smooth, and this 3-m core is best thought of as monolithologic. The total core would fall near the granodiorite-monzogranite boundary on the International Union of Geological Sciences (IUGS) diagram. For the sake of simplicity, we will refer to all samples as biotite granodiorite even though some small parts fall within the monzogranite field.

Potassium feldspar $(10-26 \%)$, plagioclase $(26-40 \%)$, quartz $(21-26 \%)$, and biotite (9-16\%) are the major constituents. Epidote (3-4\%), sphene (2-3\%), and opaques (2-4\%) are common, and there are minor amounts of chlorite, muscovite/sericite, myrmekite, calcite, apatite, zircon, prehnite, and allanite. The plagioclase in this rock is extensively altered to muscovite/sericite in contrast to the $K$-feldspar that is free of alteration. The K-feldspar is commonly poikilitic with enclosed grains of quartz, epidote, and calcite. Calcite is also present in small veinlets and stringers. Sphene is characteristically anhedral.

The chemical composition is essentially identical with the average biotite granodiorite of GT-2 and EE-1 described by Laughlin and Eddy (1977) and shown in Table IV. It apparently represents another dike or sill from the same magma source.

4. Core Number 4. The fourth core $(2.3 \mathrm{~m}$ long) from EE-2 is composed of a biotite-amphibole-quartz-plagioclase gneiss and a fine-grained biotite 
monzogranite that intrudes the gneiss. A very sharp discordant contact separates the two units.

The gneiss is composed of widely varying proportions of plagioclase $(28-45 \%)$, quartz (17-30\%), amphibole (8-25\%), and biotite (12-20\%). Potassium feldspar occurs only in trace amounts. Plagioclase shows only minor alteration to sericite; amphibole and biotite are unaltered. Anhedral to subhedral epidote makes up from 2 to $4 \%$ of the rock, and anhedral sphene from 1 to $3 \%$. Trace amounts of opaques, calcite, myrmekite, apatite, and allanite are present. The rock is a tonalitic gneiss.

Chemically the tonalitic gneiss is considerably different from the other Precambrian rock samples from GT-2, EE-1, or EE-2. Although samples of the metavolcanic of core number 2 have approximately the same silica content as the gneiss, the $\mathrm{TiO}_{2}$ and $\mathrm{K}_{2} \mathrm{O}$ contents are lower and the $\mathrm{CaO}$ content higher in the gneiss. This unit apparently has not been previously sampled by the Los Alamos drill holes.

The biotite monzogranite is a fine-grained, equigranular rock comprised primarily of K-feldspar (37\%), plagioclase (22\%), quartz (31\%), and biotite (6\%). Minor amounts of muscovite/sericite, calcite, chlorite, epidote, and opaques are present, and there are trace amounts of sphene, zircon, and allanite. The $K$-feldspar (microcline) is generally unaltered in contrast to the plagioclase, which is commonly altered to muscovite/sericite. Chlorite is present both as discrete grains and as an alteration product of biotite. Calcite appears as small stringers as well as in discrete grains.

The chemical composition of the biotite monzogranite is considerably different from that of the leucocratic monzogranite of GT-2 described by Laughi in and Eddy (1977). The silica content is lower and the $\mathrm{Al}_{2} \mathrm{O}_{3}, \mathrm{MgO}, \mathrm{CaO}$, and total Fe contents higher in the biotite monzogranite. The composition of this biotite monzogranite is also considerably different from that of the biotite monzogranite of core number 2. This unit probably represents an entirely different rock body from the other granodiorites and monzogranites.

5. Core Number 5. Core number $5(0.9 \mathrm{~m}$ 1ong) is a coarse-grained gneiss. The gneiss is composed primarily of amphibole (33\%), plagioclase $(29 \%)$, quartz (17\%), and biotite (13\%). Almost $4 \%$ muscovite/sericite is present as alteration of the plagioclase. Minor $K-f e l d s p a r$ and trace amounts of opaques, calcite, epidote, sphene, and zircon are al so present. Because of the low $\mathrm{K}$-feldspar content, this rock is a tonalitic gneiss. 
Although there is a high total muscovite/sericite content in the tonalitic gneiss, most of the plagioclase grains are free of alteration. The $K$-feldspar (microcline) and the amphibole are al so unaltered.

Chemically, this rock is characterized by relatively low $\mathrm{Al}_{2} \mathrm{O}_{3}, \mathrm{~K}_{2} \mathrm{O}$, $\mathrm{TiO}_{2}$, and $\mathrm{P}_{2} \mathrm{O}_{5}$ contents.

6. Core Number 6. Essentially all of the $1.2-\mathrm{m}$ length of core number 6 is a coarse-grained biotite granodioritic gneiss. A very thin (2- to $3-\mathrm{cm}$ ) band of fine-grained granodioritic material is present at the bottom of the core. Contacts between the gneiss and the fine-grained rock are gradational. This fine-grained rock was not analyzed.

The gneiss is composed primarily of plagioclase $(36-38 \%)$, quartz (34\%), biotite (12-15\%), K-feldspar (4-5\%), and chlorite (4-6\%). Lesser amounts of muscovite/sericite, opaques, epidote, and sphene are present, and there are trace amounts of myrmekite, calcite, and allanite. The K-feldspar (microcline) is unaltered in contrast to much of the plagioclase, which is altered to muscovite/sericite. Chlorite occurs as discrete grains and also as an alteration product of biotite.

Chemically the biotite granodioritic gneiss is similar to the biotite granodiorite of core number 3 in that the $\mathrm{K}_{2} 0$ content is significantly lower in the gneiss.

C. Results of Cuttings Analyses

The results of the analyses of the cuttings from EE-2 were used to construct the lithologic log that is shown in an abbreviated version in Fig. 2 . Rock nomenclature adheres to the system proposed by the IUGS Subcommission on the Systematics of Igneous Rocks (Fig. 1).

Because of the significance of alteration zones to the development of the Phase II HDR system, these zones will be discussed below in Sec. III.

\section{ALTERATION ZONES}

During the routine logging of drill cuttings from the lower section of $E E-2$, it became apparent that altered mineral and rock fragments were present in variable quantities in many of the samples. Depth intervals represented by these altered zones and the percentage of altered material are shown on the EE-2 litholog. A summary of the depth intervals is also given in Table $V$. 
A. Megascopic and Petrographic Description of Cuttings of Altered Rock Generally the cuttings are angular to subrounded fragments of discrete minerals and rocks, averaging 0.5 to $1.0 \mathrm{~mm}$ in diameter. The largest fragment, approximately $1.0 \mathrm{~cm}$ in diameter, was recovered in a junk basket run. The majority of the cuttings are offwhite, but some are tinted in various shades of yellow to purple. Because this coloration is present only on the exterior of the cuttings, it probably represents oxidation of iron and/or manganese after drilling.

Cuttings from 18 altered zones were prepared for microscopic examination, which indicated that, in general, the grains fall into two petrographic groups (Table VI).

The first group, represented by five thin sections from 1330 to $2614 \mathrm{~m}$ (depth along wellbore) are characterized by the presence of very finegrained calcite dispersed throughout a
GEOLOGIC CROSS SECTION, FENTON HILL HDR SITE NEW MEXICO

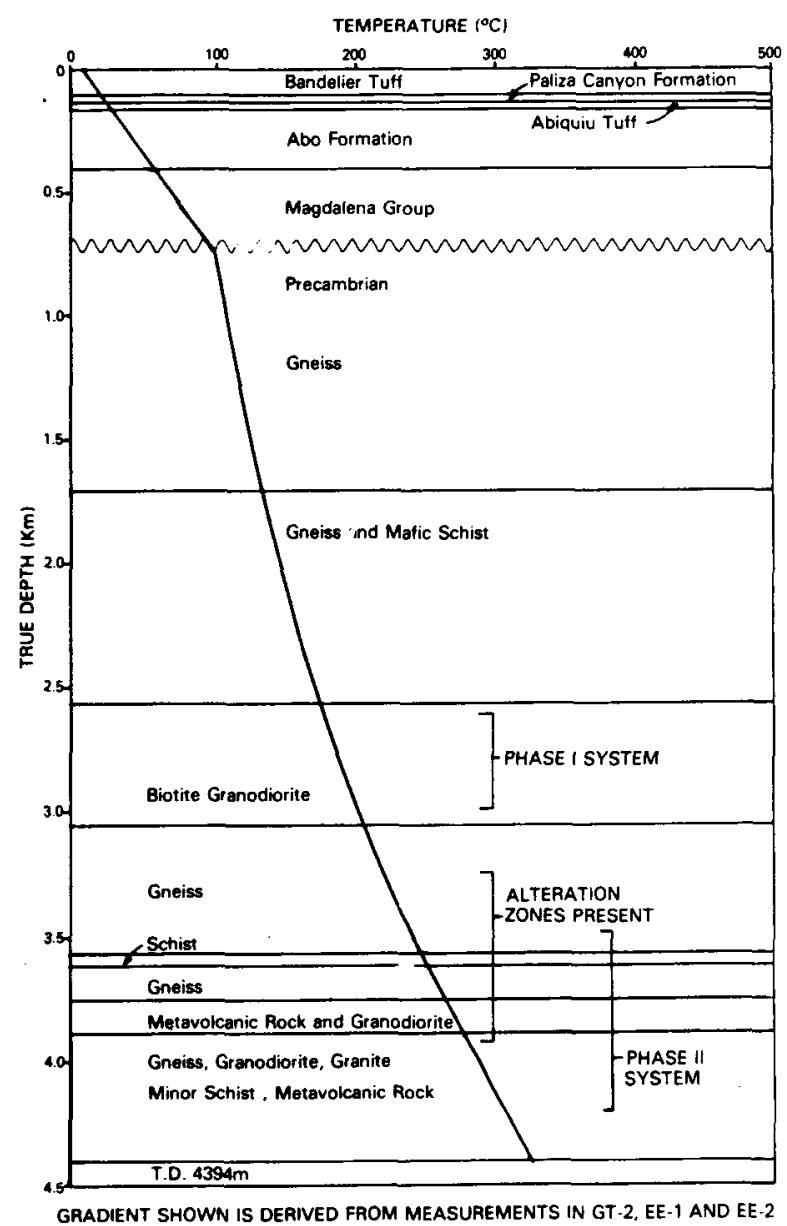

Fig. 2.

Simplified geologic cross section, Fenton Hill HDR site, New Mexico. gray microcrystalline to aphanitic groundmass. Some of the cuttings are rich in individual mineral clasts; these clasts are set in the same gray aphanitic matrix.

The second group, represented by 13 thin sections from 3193 to $4020 \mathrm{~m}$ (depth along wellbore) are characterized by an aphanitic, dark-brown to nearly opaque matrix that sometimes has a lineated to contorted, swirled appearance. This dark-brown matrix is made up of illite-montmorillonite, identified by $x$-ray diffraction study. The majority $(275 \%)$ of the altered cuttings prepared for thin sectioning in this group are composed almost entirely of mixed layer clay. Isolated fragments of angular quartz grains, generally less than $0.1 \mathrm{~mm}$ in diameter, are found scattered throughout the clay matrix. 
TABLE V

ALTERATION ZONES INTERSECTED BY EE-2 VELLBORE

Depth Along Wellbore

$(f t)$
$4360-4390$
$6220-6240$
$7240-7260$
$8430-8450$
$8570-8610$
$10070-10180$
$10300-10330$
$10440-10560$
$10990-11020$
$11060-11120$
$11220-11650$
$11800-11870$
$12050-12200$
$12250-12400$
$12470-12550$
$12660-12760$
$13180-13310$
1000

$\begin{array}{cl}\text { (m) } & \text { Amount of Alteration } \\ 1328-1337 & \leq 25 \% \text { altered grains } \\ 1894-1900 & \leq 25 \% \text { altered grains } \\ 2205-2211 & \leq 25 \% \text { altered grains } \\ 2567-2573 & \leq 25 \% \text { altered grains } \\ 2610-2622 & \leq 25 \% \text { altered grains } \\ 3066-3100 & \text { Minor alteration } \\ 3136-3145 & \text { Minor alteration } \\ 3179-3216 & \text { Extensively altered } \\ 3346-3356 & \text { Minor a lteration } \\ 3368-3386 & \text { Minor alteration } \\ 3416-3547 & \text { Extensively altered } \\ 3593-3614 & \text { Minor alteration } \\ 3669-3715 & \text { Minor alteration } \\ 3730-3776 & \text { Minor alteration } \\ 3797-3821 & \text { Minor alteration } \\ 3855-3885 & \text { Extensively altered } \\ 4013-4053 & \text { Extensively altered }\end{array}$


TABLE VI

PETROGRAPHIC SUMMARY OF THE CUTTINGS FROM ALTERED ZONES

Sample Depth (m)

1330

1897

2208

2605

2614

3193

3218

3339

3465

3547

3608

3675

3703

3819

3886

3931

4020
Basically composed of fine-grained

calcite with some individual mineral

clasts scattered throughout. The

groundmass is gray and almost aphanitic.

Basically composed of illite-montmorillonite

clays, microbreccia, and carbonate material.

The mixed layer clay dominates in abundance

and occurs as a dark-brown to nearly opaque,

aphanitic matrix in which isolated quartz

grains can be found. The microbreccla is

composed of a variety of mineral and rock

fragments showing some evidence of shattering

and plastic deformation. Some flow alignment

of the clasts is also observed. Minor

carbonate grains are also present, some

displaying zonal growth. 
Approximately $20 \%$ of the altered cuttings of the second group are composed mainly of fragments derived from the adjacent country rock. These fragments are best described as microbreccia and are characterized by small (0.1- to 0.5-mm-diam) angular grains of plagioclase, K-feldspar, quartz, biotite, amphibole, epidote, sphene, magnetite, and other minerals. Some of the biotite flakes are twisted and bent. These rock fragments typically occur in a jumbled fashion within a dark, aphanitic clay matrix; however, they occasionally show a faint fluxion alignment.

B. X-Ray Diffraction Analysis of Cuttings

Grains from seven alteration zones in EE-2 were analyzed by $x$-ray powder diffraction techniques. The percentages reported in Table VII are approximations due to the poor crystallinity of the material. With one exception, 11290, mixed layered clays dominate the mineralogy of the deep altered zones in EE-2. The abundance of calcite appears to be higher in samples from the shallower altered zones. B. H. Arney, Los Alamos National Laboratory, found (1980) that the amount of calcite present as fracture filling material also decreased with depth in the GT-2 cores. Preliminary examination of fracture filling minerals in the deeper EE-2 cores supports this observation.

c. Chemical Analysis of Cuttings

Approximately 15 grams of material from two altered zones located in the potential reservoir rock of EE-2 were chosen for chemical analysis. The results of the analyses are presented in Table VIII, Columns A and B. Several other analyses of clay from the literature are given for comparison.

The weight percentages of the various oxides from the altered material in EE-2 generally fall within the ranges from other clay analyses. However, the EE-2 altered zones are lower in $\mathrm{Al}_{2} \mathrm{O}_{3}$ and higher in $\mathrm{CaO}$ and $\mathrm{H}_{2} \mathrm{O}^{+}$. These differences are in part attributable to the fact that the material analyzed from EE-2 probably contained some microbreccia and carbonate. No attempt was made to separate the extremely small rock fragments from the mixed layer clays. However, both $x$-ray diffraction and chemical analysis confirm that the deep altered zones in EE-2 contain clay material.

Some estimate of the gain or loss of various oxides during the formation of clays can be made if we assume that the alumina content does not change significantly during alteration (i.e., if alumina is relatively immobile during low-temperature hydrothermal alteration). This assumption is commonly made when interpreting analyses of weathered rock (Krauskopf 1967). 


\section{TABLE VII}

RESULTS OF X-RAY DIFFRACTION ANALYSIS OF CUTTINGS OF ALTERED ROCK FROM EE-2. SAMPLE NUMBERS GIVE THE DEPTH IN FEET ALONG EE-2 WELLBORE ${ }^{a}$

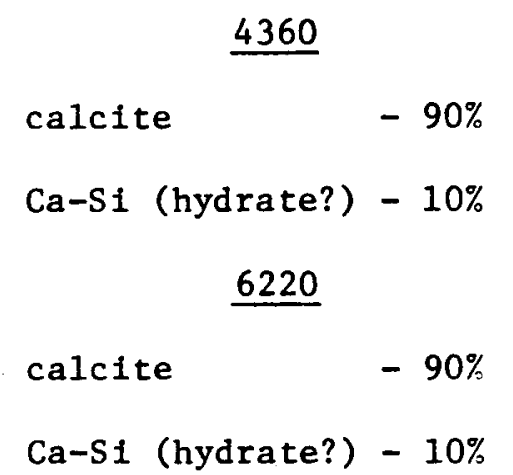

\section{0}

$\begin{array}{ll}\text { calcite } & -40 \% \\ \text { quartz } & -60 \%\end{array}$

10470

\begin{tabular}{ll} 
1llite-montmorillonite & $-60 \%$ \\
quartz & $-40 \%$ \\
& \multicolumn{11290}{l}{} \\
calcite & $-50 \%$ \\
quartz & $-45 \%$ \\
magnetite & $-5 \%$
\end{tabular}

12140

$\begin{array}{lr}\text { illite-montmorillonite } & -60 \% \\ \text { quartz } & -25 \% \\ \text { calcite } & -15 \%\end{array}$

$\underline{13180}$

111 te-montmorillonite - 55\%

$\begin{array}{ll}\text { quartz } & -25 \% \\ \text { calcite } & -20 \%\end{array}$

analyses by R. W. Charles, Los Alamos National Laboratory. 
CHEMICAL COMPOSITTON OF ALTERED ROCK FROM EE-2 AND OF ILLITE AND MONTMORILLONITE

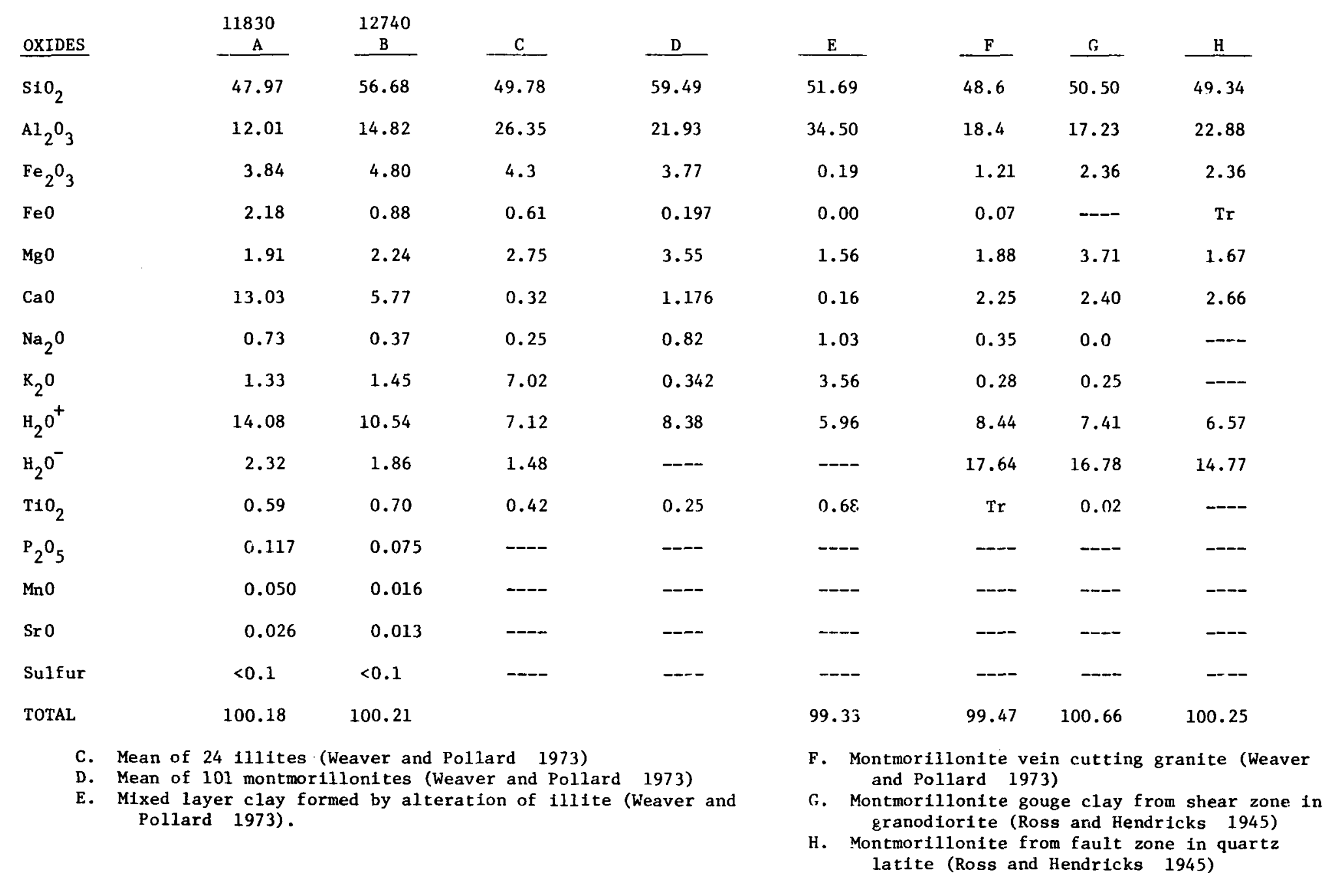


It is clear that samples 11830 and 12740 are bounded by rock very similar to the biotite granodiorite gneiss sampled by core number 1 from EE-2. If the altered material formed as a result of faulting, the host rock (the rock that supplied the material for clay formation in samples 11830 and 12740) presumably is the biotite-granodiorite gneiss.

Table IX lists the chemical analyses for samples 11830 and 12740 (Columns $B$ and $E)$ and an analysis of the biotite granodiorite gneiss from core number 1 (sample 11740-1). Assuming that $\mathrm{Al}_{2} \mathrm{O}_{3}$ has not changed during alteration, the relative percent increase or decrease of the other oxides has been calculated (Columns $C$ and $F$ in Table IX).

The dramatic increase in the water content of the two altered samples reflects the fact that these two zones are composed largely of clays that have a high capacity for $\mathrm{H}_{2} \mathrm{O}$ adsorption.

The possibility has been suggested that the altered material showing up in the cuttings might possibly be coming from one large, altered zone that experienced episodic spallations or cave-ins of material during the drilling of EE-2. The $\mathrm{H}_{2} \mathrm{O}$ content of the two analyzed altered samples would argue against this hypothesis. Clays with interlayer water will tend to systematically dehydrate with increasing temperature. Sample 12740, retrieved from a region with a temperature of approximately $256^{\circ} \mathrm{C}$, contains about $25 \%$ less water than sample 11830, retrieved from a region with a temperature of about $236^{\circ} \mathrm{C}$. The lower $\mathrm{H}_{2} \mathrm{O}$ content of the deeper clay sample is exactly what would be expected from an easily dewatered mineral.

D. Origin of Altered Zones

The presence of microbreccia, bent biotite within the microbreccia, and a crude alignment of rock fragments indicate that the altered zones have undergone shearing and are fault zones. It is impossible to determine from the presently available evidence when this faulting occurred.

Precambrian rocks beneath the Fenton Hill HDR site have probably been subjected to at least three major tectonic events. The first of these occurred 1400-1500 Myr ago during emplacement of the biotite granodiorite body within the 1700 Myr metamorphic terrain (Brookins et al. 1977, and Zartman 1979). A second probably occurred during the Laramide, coincident with formation of the Nacimiento Uplift. The most recent tectonic event occurred during formation of the Valles Caldera. Hydrothermal fluids were probably present 
TABLE IX

CHEMICAL CHANGES OCCURRING DURING FOPMATION OF ALTERED ZONES

\begin{tabular}{|c|c|c|c|c|c|c|}
\hline oxides & $\begin{array}{c}A \\
11740-1 \\
\end{array}$ & $\begin{array}{c}\mathrm{B} \\
11830 \\
\end{array}$ & $\begin{array}{c}\text { C } \\
\% \text { Change } \\
\end{array}$ & $\begin{array}{c}D \\
11740-1 \\
\end{array}$ & $\begin{array}{c}E \\
12740 \\
\end{array}$ & $\begin{array}{c}\mathrm{F} \\
\% \text { Change } \\
\end{array}$ \\
\hline $\mathrm{SiO}_{2}$ & 66.5 & 47.97 & -8.7 & 66.50 & 56.68 & -12.6 \\
\hline $\mathrm{Al}_{2} \mathrm{O}_{3}$ & 15.20 & 12.01 & 0.0 & 15.20 & 14.82 & 0.0 \\
\hline $\mathrm{Fe}_{2} \mathrm{O}_{3}$ & 1.90 & 3.84 & +155.0 & 1.90 & 4.80 & +159.0 \\
\hline $\mathrm{FeO}$ & 2.43 & 2.18 & +13.5 & 2.43 & 0.88 & -62.7 \\
\hline MgO & 1.44 & 1.91 & +67.6 & 1.44 & 2.24 & +59.3 \\
\hline $\mathrm{CaO}$ & 3.26 & 13.03 & +406.0 & 3.26 & 5.77 & +81.7 \\
\hline $\mathrm{Na}_{2} \mathrm{O}$ & 3.74 & 0.73 & -75.3 & 3.74 & 0.37 & -89.9 \\
\hline $\mathrm{K}_{2} \mathrm{O}$ & 2.71 & 1.33 & -37.9 & 2.71 & 1.45 & -44.9 \\
\hline $\mathrm{H}_{2} \mathrm{O}^{+}$ & 1.33 & 14.08 & +1234.0 & 1.33 & 10.54 & +709.7 \\
\hline $\mathrm{H}_{2} \mathrm{O}^{-}$ & 0.02 & 2.32 & +14650.0 & 0.02 & 1.86 & +9500.0 \\
\hline $\mathrm{TiO}_{2}$ & 0.74 & 0.59 & +1.4 & 0.74 & 0.70 & -2.7 \\
\hline $\mathrm{P}_{2} \mathrm{O}_{5}$ & 0.20 & 0.117 & -26.0 & 0.20 & 0.075 & -61.5 \\
\hline Mno & 0.087 & 0.050 & -26.4 & 0.087 & 0.016 & -80.5 \\
\hline Sro & 0.035 & 0.026 & -5.7 & 0.035 & 0.013 & -62.9 \\
\hline Sulfur & $<0.1$ & $<0.1$ & -- & $<0.1$ & $<0.1$ & -- \\
\hline Ṫotal & 99.59 & 100.18 & & 99.59 & 100.21 & \\
\hline
\end{tabular}


during the two tectonic events accompanied by magmatism, i.e., during Precambrian and late Cenozoic times.

Whenever the shearing occurred, the fine-grained material produced would be very susceptible to alteration by hydrothermal fluids moving along the shear or fault zones. The product of this alteration was the clays observed in the cuttings from the altered zones. Larger rock fragments, not so readily altered to clays, would then occur as lenses or streaks in a mixed layer clay matrix. Later influxes of hydrothermal fluids of the appropriate composition could then form the layered carbonate veins found throughout the altered zones. Similar carbonate veins are found along many fractures in cores from GT-2, EE-1, and EE-2.

\section{FRACTURES}

All six cores from EE-2 contain fractures that are typically sealed by a variety of minerals. The thickness of the material sealing the fracture ranges from about $0.5 \mathrm{~mm}$ in core number 1 to $2.5 \mathrm{~cm}$ in core number 4 . Sealing minerals consist of quartz, feldspars, epidote, and sometimes minor calcite, sphene, magnetite, and sulfides. Evidence for movement along some of these fractures is provided by slickensided surfaces on open fractures in core number 5 and by changes in augen orientation in regions separated by fractures in core number 4.

High in situ temperatures caused failure of photographic film in the core orienting devices and none of the cores from EE-2 were oriented. However, fracture orientations were determined from televiewer logs taken in GT-2 and EE-1 and from oriented cores from the cooler portions of GT-2. Because the three wells are separated by only short distances, the fracture orientations in EE-2 can probably be inferred to be the same as those in GT-2 and EE-1.

A. Televiewer Logs from EE-1 and GT-2

Orientations of fractures in Precambrian rocks in the EE-1 and GT-2 wells previously were determined from televiewer logs (Duffield and Tester 1978). The EE-1 televiewer logs from the depth interval 2935 to $2949 \mathrm{~m}$ were analyzed and three fracture sets identified (Fig. 3a). Unfortunately, the number of fracture planes used to construct this figure was not reported. Televiewer logs from the interval 836 to $2704 \mathrm{~m}$ in GT-2 were used to construct the histogram in Fig. 3b. Again it is not possible to determine from the reported data the actual number of fracture planes measured. 
TABLE $X$

ORIENTED CORES FROM GT-2

\begin{tabular}{|c|c|c|}
\hline Core No. & Depth of Core Interval (m) & Average Drift \\
\hline 1 & $1125.9-1128.8$ & $1.5^{\circ}, \mathrm{N} .69^{\circ} \mathrm{W}$. \\
\hline 2 & $1304.4-1305.2$ & $3.0^{\circ}, \mathrm{N} .69^{\circ} \mathrm{W}$. \\
\hline 3 & $1672.6-1670.6$ & $4.0^{\circ}, \mathrm{N} .82^{\circ} \mathrm{W}$. \\
\hline
\end{tabular}

B. Oriented Cores from GT-2

The orientations of fractures and gneissic foliation were measured in three oriented cores from GT-2 (Table $X$ ). Although over 100 fractures were observed in these cores, the attitudes of only 34 could be determined (Fig. 4); the remainder were too short or discontinuous. A contour diagram of the data (Fig. 5) indicates that the best developed fracture sets trend northeast. Two of the contour maxima appear to define fracture sets oriented $\sim N .42^{\circ} \mathrm{E}$., $81^{\circ} \mathrm{S}$ and $N .49^{\circ} \mathrm{E} ., 87^{\circ} \mathrm{S}$. (Fig. 6). The contours of these maxima overlap significantly, however, and may represent two separate fracture sets that formed at different times, a coeval conjugate pair of small dihedral angle, or a single fracture set.

A third contour maxima defines a northeast-trending fracture set $\left(\mathrm{N} .52^{\circ} \mathrm{E} ., 26^{\circ} \mathrm{N}.\right)$ that seems to be controlled by the gneissic to schistose foliation that has an average attitude of $\mathrm{N} .70^{\circ} \mathrm{E} ., 32^{\circ} \mathrm{N}$. (Fig. 7). Many of the fractures planes closely parallel the foliation; in some instances they offset it.

C. Discussion

The fracture data from oriented cores in GT-2 (Fig. 5) do not compare favorably with fracture orientations determined from televiewer logs of GT-2 or EE-1 (Fig. 3). An attempt to resolve the discrepancy by re-examining the GT-2 log over the three cored intervals failed because the quality of the $10 \mathrm{~g}$ at these intervals is too poor to be useful. 


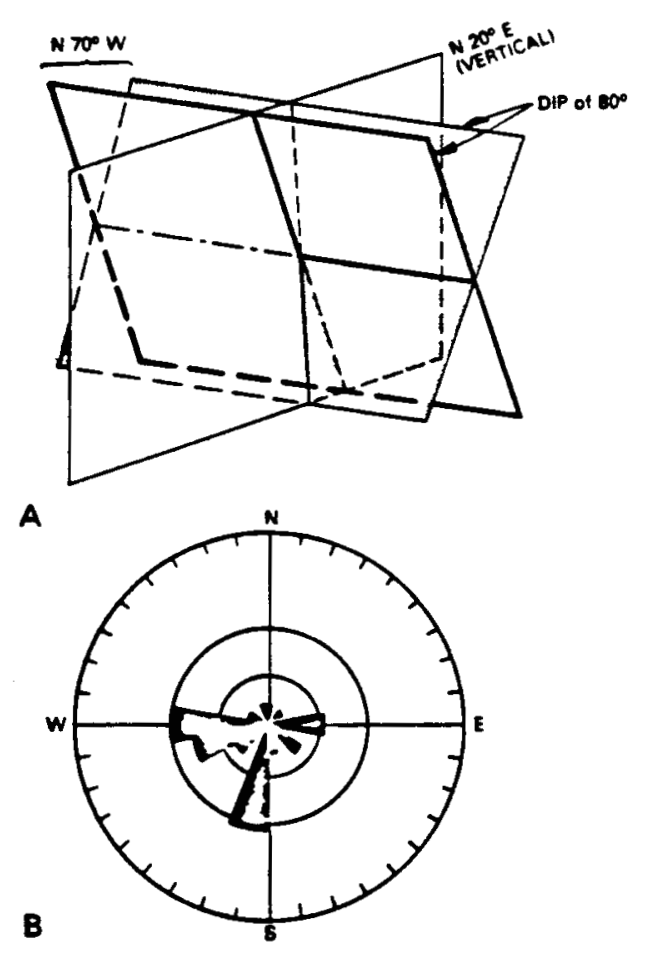

Fig. 3.

Fracture orientations from televiewer logs of Precambrian basement, Fenton Hill, Jemez Mountains. (A) Attitude of fractures mapped in the 2935- to 2949-mdepth interval in well bore $E E-1$. (B) Histogram of fracture dip angles in the 836- to 2704-m-depth interval in well bore GT-2. (From Duffield and Tester 1978, Figs. 5-51 and 5-52.)

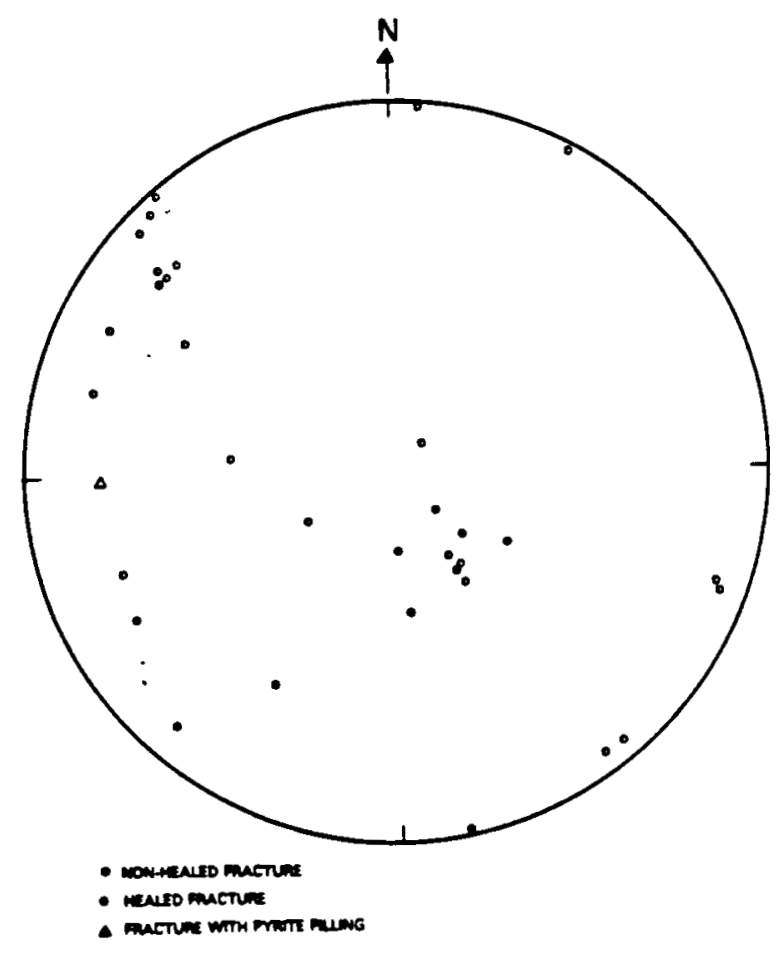

Fig. 4.

Lower hemisphere equal-area diagram of 34 fractures in oriented cores from well bore GT 2 .

Fracture orientation data from Precambrian exposures 14 to $18 \mathrm{~km}$ away on the east side of the Nacimiento uplift ${ }^{\star}$ are similar to fracture data determined from the GT-2 cores. In the outcrops the two fracture sets with greatest frequency (number of fractures per centimeter) trend north-northwest and northeast to east-northeast (Fig. 8). These di rections are consistent with

\footnotetext{
* This information was furnished by $P$. Barkman, Los Alamos National Laboratory (1980).
} 


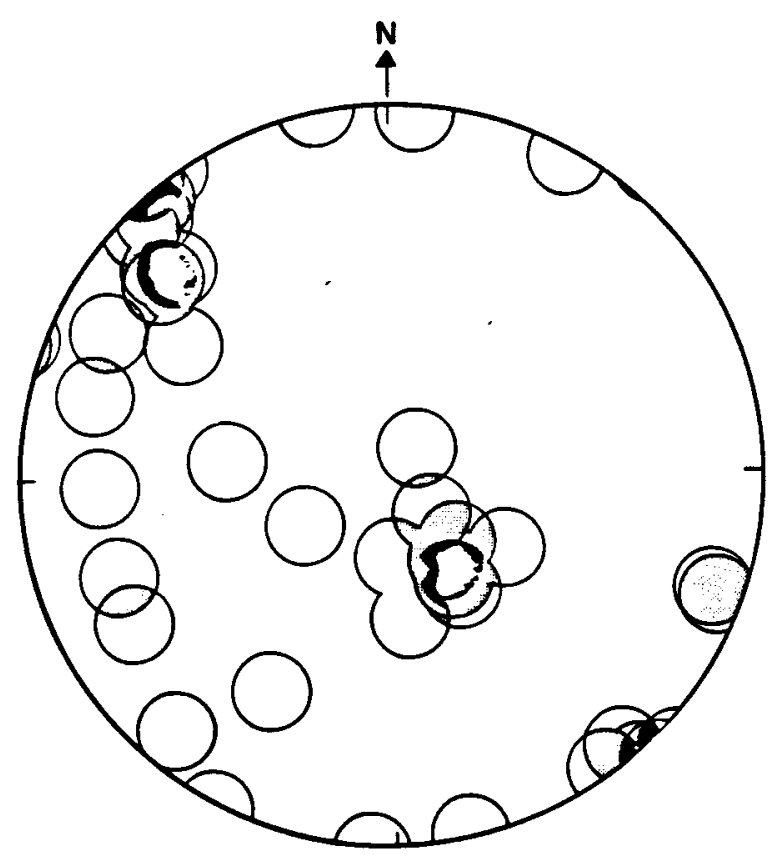

Fig. 5.

Lower hemisphere equal-area diagram of fractures in oriented cores from well bore GT-2. Contours 3, 6, $12 \%$ per $1 \%$ area.

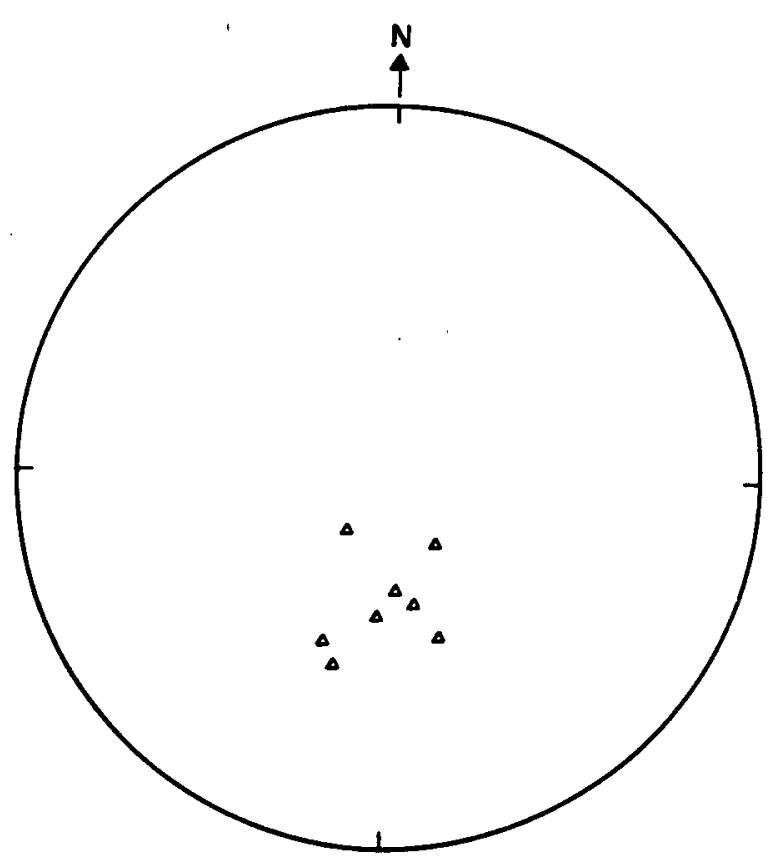

Fig. 7.

Lower hemisphere equal-area orientation diagram of gneissic foliation in GT-2 well bore between the 1126 - to $1129-\mathrm{m}-$ depth interval.

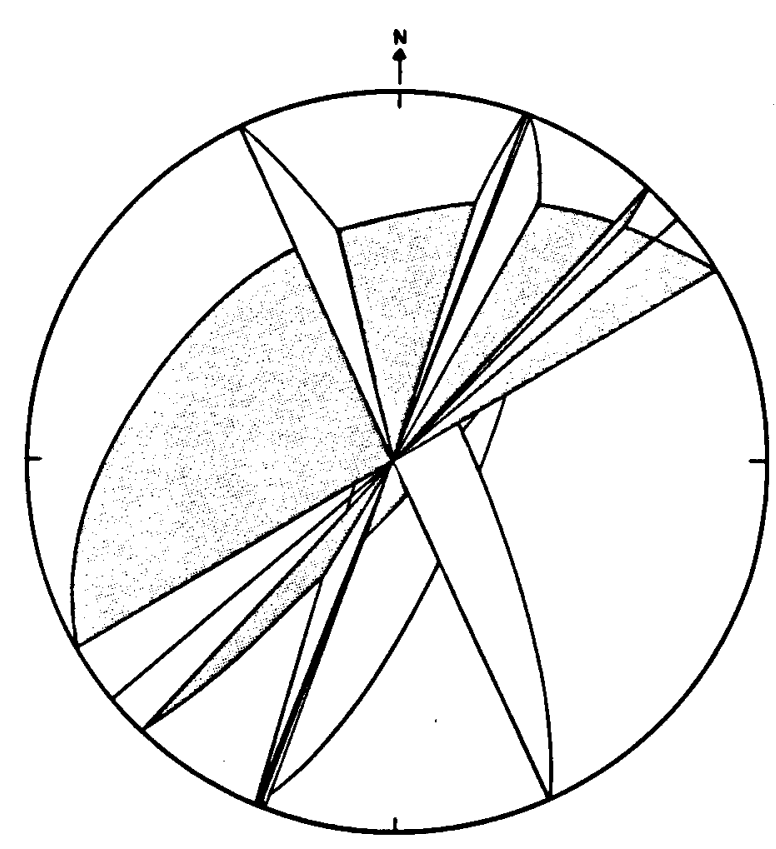

Fig. 6 .

Planes representing average attitude of fracture sets in well bore GT-2. Lower hemisphere equal-area projection. Two stippled planes and vertical plane are strongly defined. Unshaded planes are weekly defined.

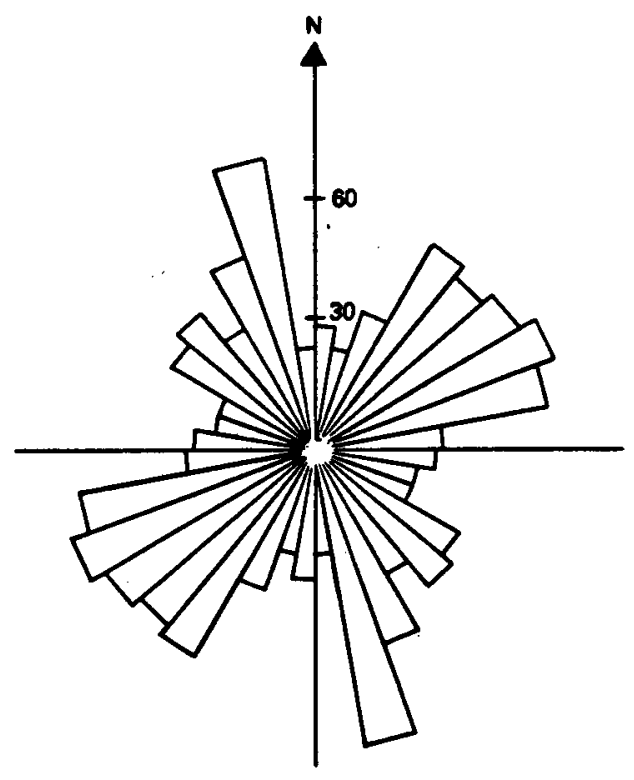

Fig. 8 .

Fracture orientations in Precambrian outcrops at Guadalupe Box on east side of Nacimiento uplift, $18.5 \mathrm{~km}$ southwest of Fenton Hill well site. 595 fractures. (See footnote, p. 27.) 
with the fracture sets trending $N$ N. $42^{\circ} \mathrm{E}$., N. $49^{\circ} \mathrm{E}$., $N \mathrm{~N} .52^{\circ} \mathrm{E}$, and $\mathrm{N} .25^{\circ} \mathrm{W}$. in the GT-2 cores. This similarity in trends suggests that the orientations of the fracture sets in the Precambrian basement at Fenton Hill are like those determined from the GT-2 cores (Fig. 4) and not as indicated by the televiewer logs (Fig. 3). The fracture sets shown in Fig. 6 are, therefore, thought to be representative of the fractures intersected by the EE-2 wellbore.

If this is correct then some interpretation of the fracture orientations in cores from EE-2 becomes possible. Of special significance are fault planes (with slickensides) found in core number 5 at a true vertical depth of about $4195 \mathrm{~m}$. The drill hole is oriented $55^{\circ}, \mathrm{N} .85^{\circ} \mathrm{E}$. at this depth, and the faults intersect the core axis at angles of $17^{\circ}$ to $24^{\circ}$, with an average angle of $21^{\circ}$. Using the assumption that the fault planes are nearly vertical, like most of the fractures in the GT-2 cores, the faults strike either $\backsim N .70^{\circ} \mathrm{W}$. or $\sim N .59^{\circ} \mathrm{E}$ and the slickensides on them plunge $18^{\circ} \mathrm{N}$. or $58^{\circ} \mathrm{S}$., respectively. Two lines of evidence indicate that the faults at the 4195-m level in EE-2 trend northeast rather than northwest:

- The closest exposed major faults to Fenton Hill, located to the south and southwest, trend northeast ( $\mathrm{N} .40^{\circ}$ to $50^{\circ} \mathrm{E}$. ).

- Northeast-trending fracture sets are well developed in basement rocks penetrated by the nearby GT-2 wellbore.

If the faults dip approximately $80^{\circ} \mathrm{S}$, as does one of the fracture sets in the GT-2 cores (Fig. 6), then their attitude is $\mathrm{N} .42^{\circ} \mathrm{E} ., 80^{\circ} \mathrm{S}$., and the slickensides rake $51^{\circ} \mathrm{S}$. The $\mathrm{N} .59^{\circ} \mathrm{E}$. (vertical) and $\mathrm{N} .42^{\circ} \mathrm{E}$. $\left(80^{\circ} \mathrm{S}\right.$. dip) trends bracket the most probable orientation of the faults.

V. IMPLICATIONS OF EE-2 GEOLOGIC INVESTIGATIONS TO THE HDR PROGRAM

Laughlin and Eddy (1977) discussed the Precambrian geology at Fenton Hill, as determined from the GT-2 and EE-1 core investigations, in light of its application to the HDR program. They particularly stressed the low permeability, chemical and mineralogic homogeneity, and mechanical isotropy of the large biotite-granodiorite body in which the Phase I system was developed.

In the previous report, the low bulk permeability of the Phase I reservoir was attributed to the fact that natural fractures were either tightly healed by recrystallization or sealed by deposition of secondary minerals, predominantly calcite. Such fractures are also common in cores from EE-2 (Phase II reservoir). In these deeper cores, however, calcite is less 
abundant as a sealing mineral and silicates, sulfides, and oxides are more common. The sealing may have occurred during any one or more of several thermal events, the most recent being emplacement of magma during formation of the Valles Caldera. Seismic activity has not reopened the sealed fractures.

Our investigations of the EE-2 cores and cuttings indicate that the potential Phase II reservoir will differ considerably from the Phase I reservoir. As shown in Figs. 2, 9, and 10 and Tables II and III, the deeper portion of EE-2, which will be developed as part of the Phase II system, is a heterogeneous metamorphic complex. The gneissic and schistose rocks show a wide range in chemical and mineralogic composition, and their foliation produces strong textural ani sotropy. Intrusive units intersected by the deeper EE-2 well bore are thin when compared with the biotite-granodiorite body encountered at shallower depths. The frequent occurrence of these small intrusive units contributes to the heterogeneity of the system.

Alteration zones contribute to the heterogeneity and anisotropy of the system and may affect its bulk permeability. If the alteration zones are fault zones, then intermittent zones of high permeability may be possible in the Phase II reservoir. Such zones could allow leakage of injected fluids and provide paths for "short circuiting" the circulating fluids.

The high clay contents of these zones suggest that they may serve as sources of fine-grained material that might plug the hydraulic fractures and facilitate slippage of adjacent competent rock during hydraulic fracturing and subsequent thermal drawdown.

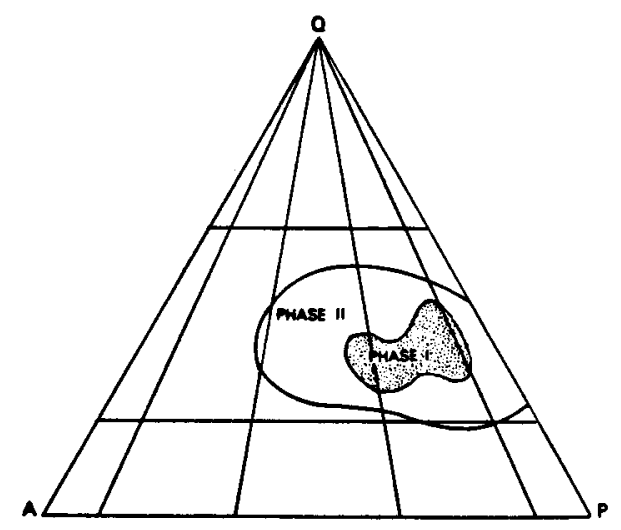

Fig. 9 .

Comparison of the compositions of reservoir rocks from the Phase I and II system. 


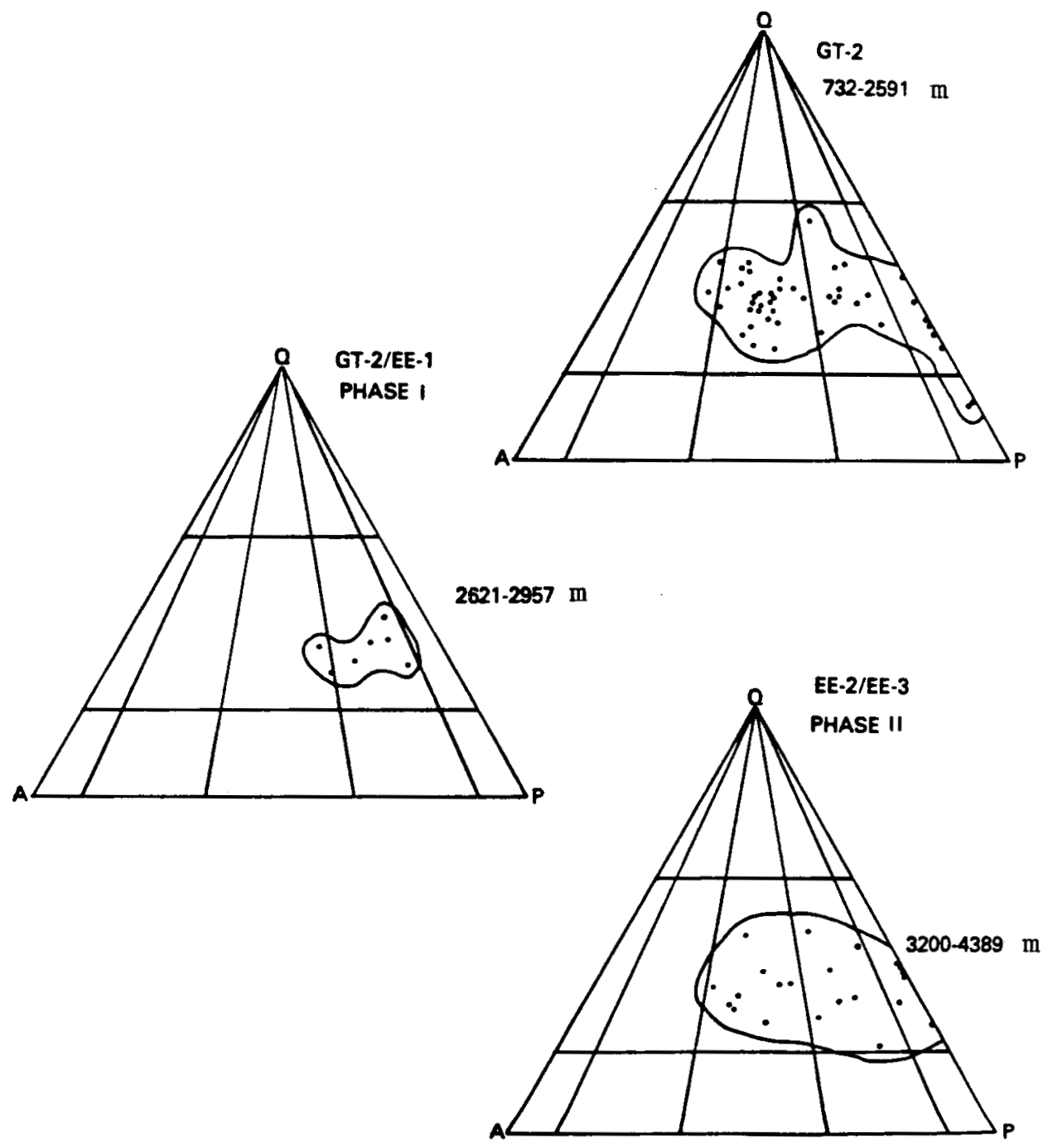

Fig. 10 .

Detailed comparison of rock composition from the Precambrian section of GT-2, the GT-2/EE-1 Phase I system, and the planned EE-2/EE-3 Phase II system. 
REFERENCES

D. G. Brookins, R. B. Forbes, D. L. Turner, A. W. Laughlin, and C. W. Naeser, " $\mathrm{Rb}-\mathrm{Sr}, \mathrm{K}-\mathrm{Ar}$ and Fission Track Geochronological Studies of Samples from LASL Drill Holes GT-1, GT-2, and EE-1," Los Alamos National Laboratory report LA-6829-MS (June 1977).

R. B. Duffield and J. W. Tester, "Reservoir Engineering," in "Hot Dry Rock Geothermal Energy Development Project Annual Report, Fiscal Year 1977," Los Al amos National Laboratory report LA-7109-PR (February 1978).

K. B. Krauskopf, Introduction to Geochemistry (McGraw-Hill Book Co., New York, $1967)$

A. W. Laughlin, "The Geothermal System of the Jemez Mountains, New Mexico and Its Exploration," in Geothermal Systems - Principles and Case Histories, $L$. Rybach and L. J. P. Muffler, Eds. (John WiTey and Sons, Inc., 1981) pp. 295-320.

A. W. Laughlin and A. C. Eddy, "Petrography and Geochemistry of Precambrian Core Samples from GT-1 and EE-1," (Abst) EOS, Trans. Amer. Geophys. Union, 57, 1976.

A. W. Laughlin and A. C. Eddy, "Petrography and Geochemistry of Precambrian Rocks from GT-2 and EE-1," Los Alamos National Laboratory report LA-6930-MS (August 1977).

C. S. Ross and S. B. Hendricks, "Minerals of the Montmorillonite Group," U.S. Geol. Surv. Prof. Paper 205-B, 1956.

C. E. Weaver and L. D. Pollard, "The Chemistry of Clay Minerals," Dev. Sedimental 16, 1973.

F. G. West, "Regional Geology and Geophysics of the Jemez Mountains," Los Alamos National Laboratory report LA-5362-MS (August 1973).

F. G. West and A. W. Laughlin, "Spectral Gamma Logging in Crystalline Basement Rocks," Geology $\underline{4}, 1976$.

R. E. Zartman, "Uranium, Thorium, and Lead Concentrations and Lead Isotopic Compositon of Biotite Granodiorite (Sample 9527-2b) from LASL Drill Hole GT-2," Los Alamos National Laboratory report LA-7923-MS (July 1979). 